\title{
MENJADI MUSLIM MINORITAS DAN POLA PEMBELAJARAN BAHASA ARAB BERBASIS PESANTREN
}

\author{
Bukhori \\ Fakultas Ilmu Sosial dan Ilmu Politik, UIN Sunan Gunung Djati Bandung \\ Email: bukhori@gmail.com
}

\begin{abstract}
Abstrak
Pesantren memiliki sejarah panjang dalam pengembangan sistem pendidikan nasional di Indonesia. Ini inisiatif diperluas melalui Indonesia, termasuk ke daerah minoritas muslim. Karena itu, makalah ini akan mengeksplorasi bagaimana pesantren terlibat dalam aktivitas mereka dalam mengajar dan belajar bahasa asing. Bahasa asing tersebut adalah Arab dan Inggris. Studi ini hanya akan fokus pada bahasa Arab sebagai sumber utama pemahaman Islam. Penelitian dilakukan di Pesantren Ummi Kalsum, Kabupaten Gunung Sitoli-Nias, Indonesia. Pendekatan kualitatif digunakan selama siklus belajar. Wawancara mendalam dan observasi non-partisipan dilakukan untuk mengumpulkan data. Pengumpulan data dilakukan dari Februari hingga Mei. Temuan penelitian menunjukkan bahwa pesantren melestarikan proses belajar mengajar tradisional Arab. Mereka masih melakukan badongan (individu) dan sorogan (klasik). Selain melakukan ini, mereka melanjutkan strategi dan metode lain untuk meningkatkan keterampilan bahasa siswa. Ada tujuh belas latihan itu pesantren dilakukan. Program-program tersebut terhubung melalui 24 jam antrian lingkungan hidup. Akhirnya, teknik dan kegiatan diterapkan untuk memperluas prestasi bahasa siswa.
\end{abstract}

Kata Kunci: pesantren, pengajaran, belajar, Muslim, sekolah.

\begin{abstract}
Pesantren has a long history of developing the national education system in Indonesia. This initiative was expanded through Indonesia, including to Muslim minority areas. Therefore, this paper will explore how pesantren are involved in their activities in teaching and learning foreign languages. The foreign languages are Arabic and English. This study will only focus on Arabic as the primary source of understanding of Islam. The study was conducted at the Islamic Boarding School Ummi Kalsum, Gunung Sitoli District, Nias, Indonesia. A qualitative approach is used during the learning cycle. In-depth interviews and nonparticipant observation were conducted to collect data. Data collection is held from February to May. Research findings indicate that pesantren preserve the traditional Arabic teaching and learning process. They still do badongan (individual) and sorogan (classic). In addition to doing this, they continue other strategies and methods to improve students' language skills. Seventeen pesantren exercises were carried out. These programs are connected through 24-hour environmental queues. Finally, techniques and activities are applied to broaden students' language achievement.
\end{abstract}

Keywords: pesantren, teaching, learning, Muslims, schools. 


\section{A. PENDAHULUAN}

Ada beberapa masalah yang menjadi fokus utama penelitian ini, yaitu hubungan antara (i) pendidikan bahasa Arab, (ii) pesantren, dan (iii) budaya. Bahasa adalah bagian penting sebagai media di mana manusia berkomunikasi satu sama lain. Namun, bahasa Arab tidak hanya digunakan untuk komunikasi manusia tetapi juga bahasa yang dipilih untuk beribadah dalam Islam. Karena itu, bahasa Arab memegang tempat khusus dan penting sebagai bahasa yang digunakan dalam kegiatan keagamaan . Baring (2011) menyatakan agama dan budaya (termasuk bahasa Arab) sebagai penyatuan prinsip yang tidak dapat dipisahkan dari pembelajaran. Islam adalah esensi utama budaya Arab. Kemudian, budayanya adalah Arab, yang memiliki tempat khusus dalam Islam. Budaya Arab mempengaruhi berbagai budaya Islam. Sehubungan dengan ini, kita harus menghindari pemahaman bahwa keduanya adalah satu yang sama atau berjalan bersama secara eksklusif. Bahasa Arab adalah bahasa yang penting bagi komunitas Muslim di mana-mana karena itu adalah bahasa ibadah, bahasa yang sering digunakan oleh umat Islam dan bahasa yang diyakini oleh semua orang sebagai bahasa yang dipilih oleh Allah (Boudelaa \& MarslenWilson (2013). Hal ini dapat diamati dalam penggunaan bahasa Arab selama ritual penyembahan dalam Islam, di mana dalam doa, haji dan segala macam kegiatan ibadah umat Islam lainnya harus dilakukan dalam bahasa Arab. Agama berusaha membentuk individu dalam mempertahankan kegiatan selama hidupnya. Fenomena ini memproses untuk mengkonseptualisasikan dunia sosial dan tempat (Pace, 2011). Akhirnya, ada kebutuhan untuk memeriksa pengajaran dan pembelajaran bahasa Arab. Pesantren dipilih sebagai lokasi studi, di mana bahasa Arab diajarkan secara intensif. Artikel ini akan mengeksplorasi bagaimana pesantren di Kabupaten Gunung Sitoli-Nias, Indonesia menerapkan pengajaran dan pembelajaran dalam bahasa Arab.

Dalam literatur peradaban Islam, ada catatan tentang Arab yang sejalan dengan berbagai kekaisaran atau perkembangan peradaban (Wolfe, 2017), di mana Islam tidak dapat dipisahkan dari pertumbuhan sastra dan budaya Arab. Ini termasuk linguistik, puisi, dan sejarah. Pada tahap awal, pengamatan dilakukan oleh masyarakat perkotaan dunia Arab pada bahasa Arab, didorong oleh dorongan untuk mempelajari Alquran sebagai mutlak. Memahami Alquran tergantung pada keterampilan memahami bahasa Arab, sebagai bagian dari budaya yang terkait dengan bahasa Arab. Selain itu, literatur Arab diperbarui untuk mencerminkan, menjelaskan, dan sejajar dengan Alquran. Kunci utama untuk menghargai Al-Quran itu sendiri adalah melalui pemahaman bahasa. Bahasa bagi seorang filolog adalah 
salah satu elemen terpenting dari suatu peradaban, dan mereka membatasi peradaban menjadi satu bahasa, atau dari sekelompok bahasa tunggal yang terkait melalui akulturasi. Definisi ini disajikan oleh Uhlmann (2017). Secara khusus, bahasa Arab di Indonesia telah diedarkan melalui pembelajaran di pesantren. Selain itu, pesantren adalah lembaga khusus yang bertujuan untuk memperkuat pemahaman Islam sebagai agama dari berbagai aspek termasuk pemahaman mendalam tentang bahasa Arab sebagai alat untuk mengetahui tentang Islam. Pesantren adalah lembaga pendidikan khusus yang berakar pada sejarah panjang pendidikan di Indonesia. Lembaga pendidikan Islam mulai berkembang sekitar tahun 1831, setelah pemisahannya dari istana.

Dengan peran penting dibiarkan terbuka, pesantren mengambil peran yang paling penting di masyarakat. Pesantren sangat peduli dalam memberdayakan masyarakat terutama di bidang pendidikan (Lawson, 2010; Scott, 2011). Peran ini dimainkan secara independen dan konsisten. Setelah melalui proses yang panjang, pesantren akhirnya diberi tanggung jawab dan kepercayaan oleh masyarakat sebagai pusat keunggulan pendidikan Islam. Lebih jauh, ketika seorang anggota masyarakat memiliki masalah terkait dengan pendidikan dan agama, pesantren menjadi titik rujukan pertama dan utama. Ini menunjukkan betapa sangat dihargainya bagian penting pesantren dari masyarakat Indonesia. Sebelum Indonesia merdeka, pesantren sudah ada. Pesantren adaptasi dalam mendukung pengajaran dan pembelajaran menunjukkan bahwa lembaga menerapkan teknologi komunikasi informasi sebagai bagian dari pengajaran (Wekke dan Hamid, 2013). Penyesuaian ini merupakan inisiatif untuk memungkinkan guru dan siswa dalam memperoleh perspektif modern. Di sisi lain, agama adalah tentang tradisi dan budaya, tetapi praktik ini dalam mempertahankan pencapaian fitur tinggi beasiswa. Perspektif lain disajikan Wekke dan Lubis (2008) dalam mengeksplorasi latar belakang multikultural tentang menciptakan instruksi di lingkungan pesantren. Penelitian-penelitian itu sebagai kesimpulan bahwa pesantren tidak memisahkan aktivitas mereka dari perkembangan baru-baru ini di dunia. Mereka mencoba memperluas organisasi sebagai bagian dari peningkatan modern. Pesantren terkenal dengan pengembangan dari dalam inisiatif. Ini adalah tempat yang damai untuk berpartisipasi melalui pertumbuhan bangsa. Sejarah menunjukkan bahwa mulai dari kegiatan keagamaan, baru-baru ini organisasi memasok kemajuan pendidikan, keterlibatan lingkungan, dan kontribusi politik. Lembaga-lembaga ini memiliki tempat khusus bagi masyarakat, karena mereka bergabung dalam banyak cara hidup. 


\section{B. METODE}

Penggunaan rencana penelitian dalam penelitian ini mengacu pada beberapa hal. Tujuan dari penelitian ini adalah untuk menemukan metode untuk belajar bahasa Arab dan untuk itu, ia menggunakan rencana penelitian kualitatif dengan pendekatan fenomenologis. Karena jenis penelitian yang didasarkan pada teori, dan fitur karakteristik kualitatif, maka penelitian ini bertujuan untuk memahami pendekatan yang didasarkan pada objek yang secara empiris tidak terbatas, yang tidak berarti pemikiran spekulatif, sebagai gantinya diarahkan pada penggunaan kapasitas manusia untuk berpikir secara reflektif menggunakan logika. Teori Beralas di sini berarti bahwa penelitian ini dimaksudkan untuk mengembangkan konsep dari data yang dikumpulkan. Teknik pengumpulan data utama dalam penelitian ini adalah melalui observasi dan wawancara. Pertama, teknik observasi yang digunakan adalah observasi non partisipan. Dengan cara ini, kehadiran peneliti di lokasi penelitian tidak mempengaruhi kegiatan interaksi, sehingga data yang dikumpulkan bersih tanpa pengaruh eksternal. Pengamatan dilakukan selama 2 (dua) bulan. Pengumpulan data dimulai Desember 2017 hingga Januari 2018. Kedua, data yang tidak diperoleh dengan observasi dikumpulkan dari wawancara. Wawancara dilakukan untuk mengumpulkan data tentang pandangan guru tentang pelaksanaan pembelajaran bahasa Arab.

\section{HASIL DAN PEMBAHASAN}

Pesantren Ummi Kalsum adalah lembaga modern yang menggunakan standar profesional dan secara aktif terlibat dalam pengembangan pendidikan (mental dan spiritual) dengan visi untuk menjadi mitra masyarakat yang secara aktif membantu, mendidik dan menghasilkan generasi dengan jiwa Quran seorang, baik dan visioner. Misi utama Pesantren Ummi Kalsum adalah untuk membentuk generasi berikutnya yang sholeh (saleh), yang selalu membela Aqidah (iman), berperilaku seperti yang diperintahkan oleh Alquran, baik hati, berbakti kepada orang tua dan tua, bermanfaat untuk agama, masyarakat dan bangsa. Yayasan ini tidak hanya menjadi cetakan untuk menguasai pengetahuan agama tetapi juga subjek lainnya. Untuk itu, belajar bahasa Arab telah menjadi syarat penting. Budaya yang memengaruhi belajar-mengajar bahasa Arab di Pesantren Ummi Kalsum melibatkan masalah-masalah kehidupan sehari-hari di lingkungan sekitarnya, melihat bahwa bahasa perlu dipraktikkan dan dijadikan kebiasaan sehari-hari. Pada saat yang sama, lingkungan juga mempengaruhi pembelajaran bahasa, dan hal yang sama berlaku untuk belajar bahasa Arab. Siswa pesantren tidak dibebaskan dari diskusi budaya di kabupaten di mana pesantren berada. 
Oleh karena itu, tidak mengherankan bahwa itu akan mempengaruhi sistem belajar-mengajar bahasa Arab di sana, khususnya, pola pikir para siswa. Siswa dari berbagai latar belakang dan budaya, dan latar belakang mereka sedikit mempengaruhi, jika tidak banyak, belajarmengajar bahasa Arab. Misalnya, siswa di Pesantren Ummi Kalsum berasal dari berbagai kabupaten, ada yang dari Papua dan ada yang dari luar. Karakteristik orang di Papua berbeda dari yang lain, baik itu dalam hal bagaimana mereka saling menyapa, melakukan kegiatan dan sebagainya. Selain itu, rencana pembelajaran untuk pesantren perlu membantu proses belajar-mengajar. Temuan di atas menunjukkan kebutuhan untuk mengetahui dan memahami budaya lain karena dalam arti, pengalaman interaksi antara budaya yang berbeda masih relatif kurang. Demikian juga dalam pendidikan formal, kurikulum untuk pendidikan sosial dan budaya sangat minim. Keanekaragaman dalam populasi Indonesia akan menjadi lebih menarik ketika mengalami akulturasi, yang akan bertindak sebagai mekanisme adaptasi sosial. Ada juga kebutuhan untuk membangun lingkungan belajar yang memungkinkan siswa untuk belajar dalam suasana yang didukung. Spirit of Islam memberikan siswa untuk belajar dalam kesempatan maksimal untuk memperoleh bahasa. Mereka ingin berpikir bahwa melalui penguasaan bahasa sebagai titik awal dalam memahami agama. Tanpa pertimbangan ini, tidak akan membantu dalam mempertahankan afiliasi mereka untuk memahami doa, dan komponen kegiatan agama lainnya. Oleh karena itu, perlu dilakukan upaya untuk menemukan dalam banyak cara untuk mendukung pendidikan dan bahasa. Mereka menciptakan banyak kegiatan hingga 24 jam di asrama dan waktu sekolah. Tujuannya adalah untuk memperluas batas dan memaksimalkan potensi siswa dalam mendapatkan bahasa. Bagian utama dari Islam adalah memahami bahasa Arab sebagai bahasa komunikasi agama. Ketika mereka melakukan banyak kegiatan dalam sholat, membaca Alquran, memahami Hadits (ucapan Nabi), semua materi tersedia dalam bahasa Arab. Selain itu, ada kebutuhan untuk memiliki pemahaman yang bermakna terhadap bahasa tersebut. Sebagai bagian dari kurikulum, sekolah menyediakan banyak pelajaran dan pelatihan dalam menghadirkan kesempatan untuk belajar.

\section{TEMUAN DAN DISKUSI}

Budaya pendidikan merupakan elemen penting dalam tradisi yang berkelanjutan. Temuan penelitian ini sejalan dengan teori budaya pendidikan Frempong, Reddy \& Kanjee (2011) yang mengatakan bahwa melalui budayalah seorang siswa mendapatkan pengalaman dan perkembangan manusia. Oleh karena itu, guru harus memperhatikan perilaku siswa 
karena setiap siswa berbeda. Ini juga disebutkan dalam teori yang disampaikan oleh Albert (2010). Dengan mempertahankan budaya pendidikan, siswa akan terus merespons (Felderhof, 2010). Untuk itu, guru harus mengamati perbedaan latar belakang siswa (Yong, 2011) karena setiap siswa memerlukan perlakuan yang berbeda ( Boudreau, 2011) juga untuk amati perbedaan usia (Caron \& Ahlgrim, 2017). Perbedaan budaya dan negara membuat hidup kita berbeda dan gaya hidup kita berbeda satu sama lain. Baik itu dari segi bahasa, agama, selera dan sebagainya. Ini pada akhirnya menunjukkan bahwa pedoman yang kita butuhkan harus akurat, terarah, dan sesuai dengan lingkungan kita. Namun, kita harus tetap berpegang teguh pada aturan, cara, dan pengetahuan sejati dalam panduan kita. Sebagai seorang guru, itu adalah suatu keharusan untuk dapat mengkondisikan diri mereka sendiri, dan untuk mencapai siswa, mereka harus dapat membedakan dan mengetahui strategi yang harus diambil dan strategi yang dapat diambil (Murphy, 2011).

Davis (2010) dan Caron \& Ahlgrim (2017) melakukan penelitian yang berfokus pada beberapa negara, seperti Amerika Serikat, Inggris, dan Swedia. Sementara itu, penelitian difokuskan untuk menemukan persamaan dan perbedaan antara mahasiswa dari dua kampus dengan melihat hubungan mereka dengan teman-teman. Di antara kedua negara, perbedaan yang dapat ditemukan ditemukan. Jelas, temuan penelitian Rossiter (2010) mengejutkan karena ada banyak perbedaan yang ditemukan dalam hal perilaku sosial antara kedua negara. Mungkin, yang lebih menarik adalah bahwa para siswa di Brunei Darussalam dilaporkan lebih banyak berinteraksi dan bahwa mereka memiliki lebih banyak waktu luang untuk interaksi sosial dengan teman-teman mereka (Lubis dan Wekke, 2009; Paugh \& DudleyMarling, 2011). Ini menunjukkan bahwa interaksi dan waktu bersosialisasi dapat mendukung upaya untuk mencapai tujuan pembelajaran. Sebagaimana dinyatakan oleh Dehqan (2009) dan Moore (2001), sumber daya manusia yang berkualitas melibatkan tiga dimensi, yaitu pertama, dimensi ekonomi, kedua, dimensi budaya, dan ketiga, dimensi spiritual ( iman dan taqwa atau iman dan kesalehan). Upaya untuk meningkatkan kualitas sumber daya manusia melalui pendidikan juga perlu merujuk pada penambahan nilai pada dimensi ketiga. Peningkatan bisa dilakukan melalui proses seperti akulturasi, pengembangan iman, dan pengembangan pengetahuan dan teknologi. Proses akulturasi adalah proses transformasi nilai-nilai budaya yang meliputi etika, estetika dan budaya, serta visi nasional dalam rencana untuk mengembangkan manusia yang beradab. 


\section{E. KESIMPULAN}

Budaya yang tampak jelas di pesantren memberikan makna bagi perkembangan pembelajaran bahasa Arab, khususnya di lingkungan di mana ia dikembangkan. Menurut penelitian ini, yang berbeda dari penelitian sebelumnya di mana mereka hanya berfokus pada beberapa sistem implementasi, sistem kinerja untuk belajar bahasa Arab disarankan dalam mendukung pengembangan lingkungan untuk mendukung proses belajar-mengajar di pesantren . Karena itu, proses implementasi pembelajaran bahasa Arab bisa lebih intensif. Model pesantren di mana muslim adalah minoritas mencerminkan bahwa lingkungan pengajaran adalah bagian dari pendidikan. Memang, lingkungan dapat diciptakan untuk mendukung proses pembelajaran. Pesantren Ummi Kalsum di mana minoritas muslim dalam konteks Indonesia adalah mayoritas, mereka melestarikan budaya mereka sendiri untuk mendukung tujuan pendidikan Islam. Kondisi muslim minoritas bukanlah variabel untuk menghilangkan semangat dalam belajar bahasa Arab. Konsep mereka tentang kebutuhan akan bahasa menawarkan upaya untuk membangun sebagai model pelatihan. Pendekatan, strategi, dan metode yang diterapkan di sekolah lain diadopsi dan disesuaikan dengan kondisi setempat.

\section{DAFTAR PUSTAKA}

Alberts, W. (2010). Studi akademik agama dan pendidikan agama integratif di Eropa. Jurnal Pendidikan Agama Inggris, 32 (3), 275-290.

Baring, RV (2011). Pluralitas dalam persatuan: tantangan menuju pendidikan agama di Filipina. Pendidikan Agama: Jurnal resmi Asosiasi Pendidikan Agama, 106 (5), 459475.

Boudelaa, S. \& Marslen-Wilson, WD (2013). Struktur morfologis dalam leksikon mental Arab: Paralel antara bahasa Arab standar dan dialek. Bahasa dan Proses Kognitif, 28 (10), 1453-1473.

Boudreau, S. (2011). Dari pengakuan hingga budaya: pendidikan agama di sekolah-sekolah Quebec. Agama \& Pendidikan, 38(3), 212-223.

Caron, SL \& Ahlgrim, CJ (2017). Pemahaman dan pengetahuan anak-anak tentang konsepsi dan kelahiran: membandingkan anak-anak dari Inggris, Belanda, Swedia, dan Amerika Serikat. American Journal of Sexuality Education, 7(1), 16-36.

Davis, A. (2010). Mempertahankan pluralisme agama untuk pendidikan agama. Etika dan Pendidikan, 5(3), 189-202.

Dehqan, M. (2009). Penulis Kurdi dalam kamus biografi Arab. Jurnal Informasi Agama \& Teologis, 7 (3-4), 171-179. Felderhof, M. (2010). Kemunduran dan pendidikan agama Inggris. Jurnal Keyakinan \& Nilai: Studi di Agama \& Pendidikan, 31(2), 155-164.

Frempong, G. Reddy, V. \& Kanjee, A. (2011). Menjelajahi Pemerataan dan Pendidikan Berkualitas di Afrika Selatan Menggunakan Model Bertingkat. Jurnal Pendidikan Komparatif dan Internasional, 41(6), 819-835. 
G. Rossiter (2010). Perspektif spiritualitas kontemporer: implikasi bagi pendidikan agama di sekolah-sekolah Katolik. Studi Internasional dalam Pendidikan Katolik, 2(2), 129147.

Lawson, DR (2010). Penilaian sistem transliterasi Arab. Layanan Teknis Quarterly, 27(2), 164-177.

Lubis, MA \& Wekke, IS (2009). Pendidikan Islam terpadu di Brunei Darussalam: harapan dan tantangan. PENDIDIKAN: Jurnal Internasional untuk Studi Pendidikan, 1(2), 141-156.

Murphy, AR (2011). Agama, agama sipil, dan perang saudara: iman dan hubungan luar negeri di kepresidenan Lincoln. Ulasan Faith \& International Affairs, 9 (4), 21-28.

PC Paugh \& C. Dudley-Marling (2011). Defisit 'Berbicara' menjadi (atau tidak ada): bagaimana bahasa membatasi pengetahuan guru kelas tentang pengajaran beragam pelajar. Jurnal Internasional Pendidikan Inklusif, 15(8), 819-833.

Pace, E. (2011). Agama sebagai komunikasi. Revue Internationale de Sociologie, 21(1), 205229.

R. Moore. (2001). Menggunakan web dalam kursus studi agama. Jurnal Informasi Agama \& Teologis, 3(3-4), 139-150.

Scott, DG (2011). Spiritual sebagai sesuatu yang kritis dan politis. Jurnal Internasional Spiritualitas Anak, 16(4), 293-299.

Uhlmann, AJ (2017). Bahasa Arab dan instruksi tata bahasa Arab di universitas-universitas Israel: alterity, alienation and dislocation. Kritik Timur Tengah, 21(1), 101-116.

Wekke, IS \& Hamid, S. (2013). Teknologi Pengajaran dan Pembelajaran Bahasa: Penelitian tentang Pesantren Indonesia. Procedia-Ilmu Sosial dan Perilaku, 83, 585-589.

Wekke, IS \& Lubis, MA (2008). Pendekatan Multikultural dalam pengajaran bahasa Arab: menciptakan kesetaraan di kehidupan kelas pesantren Indonesia. Sosiohumanika, 1(2), 295-310.

Wolfe, P. (2017). Terjemahan Bahasa Arab: Pemukim Kolonialisme dan Penghapusan Penduduk Asli. Studi Kolonial Settler, 2(1), 226-252.

Yong, A. (2011). Cacat Dari Pinggiran Ke Pusat: Keramahtamahan dan Inklusi di Gereja. Jurnal Agama, Kecacatan \& Kesehatan, 15(4), 339-350. 